\title{
The Leacock Mission Statement
}

\section{by Ian Binnie}

This talk was given at the annual Leacock Luncheon of the Graduates' Society of McGill University held in Montreal on Friday, 1 October, 1993.

Cette conférence a été prononcée à l'occasion du banquet Leacock de l'Association des diplômés de l'Université McGill qui a eu lieu à Montréal le vendredi $1^{\text {er }}$ octobre 1993.

$\mathrm{W}$ hen Stephen Leacock was asked why he continued to smoke and drink into his old age he pointed out that if caught in a medical emergency without nicotine and alcohol he would be like a ship caught in a storm without any excess freight to throw overboard.

Much the same spirit of whimsy and self-parody no doubt moved McGill recently to take aboard something called the Mission Statement, a lugubrious document drafted by the University Task Force on Priorities in May 1991, and subsequently endorsed by the Senate and Board of Governors of the University in the Spring of 1991.

This document is the blueprint for Harvard North - or, to put it another way, a repudiation of everything Professor Leacock ever stood for.

McGill's new \$200 million fund raising campaign ("the McGill 21st Century Fund") is apparently to be built around the theme of the Mission Statement, namely an unhealthy preoccupation with the pursuit of excellence, and in particular:

- scholastic excellence

- teaching excellence, and

- research excellence.

The self-congratulatory tone of the Mission Statement is, I think, quite foreign to the spirit of scepticism that is supposed to animate a centre of learning.

Inflated thetoric is better left to politicians rather than professors. We have only to remember the great Free Trade Election of 1984. Mr. Mulroney, in each of his stomach-churning appearances, lectured us to pull the finger out and become competitive and "world class." The voters, suitably bewildered by all of the oratory, gave Free Trade their overwhelming support - like turkeys calling for an early Christmas.

In the next few minutes I propose to review with you the text of McGill's Mission Statement. I hope to demonstrate that my criticism is, if anything, understated. Lest this lecture be considered a wholly negative exercise, moreover, I will then propose an alternative Mission Statement more in tune, I think, with Professor Leacock's philosophy. It will then be for you to choose which of these approaches best represents the enduring values of old McGill.

Here is what the official McGill Mission Statement presently says:

The mission of McGill University is the advancement of learning through teaching, scholarship, and service to society: by offering to outstanding undergraduate and graduate students the best education available; by carrying out scholarly activities judged to be excellent when measured against the highest international standards; and by providing service to society in those ways for which we are well suited by virtue of our academic strengths.

The Mission Statement is built around the concept of "advancement of learning through teaching," but the McGill teachers of my day would have been appalled at the accusation of being world class intellectuals. 


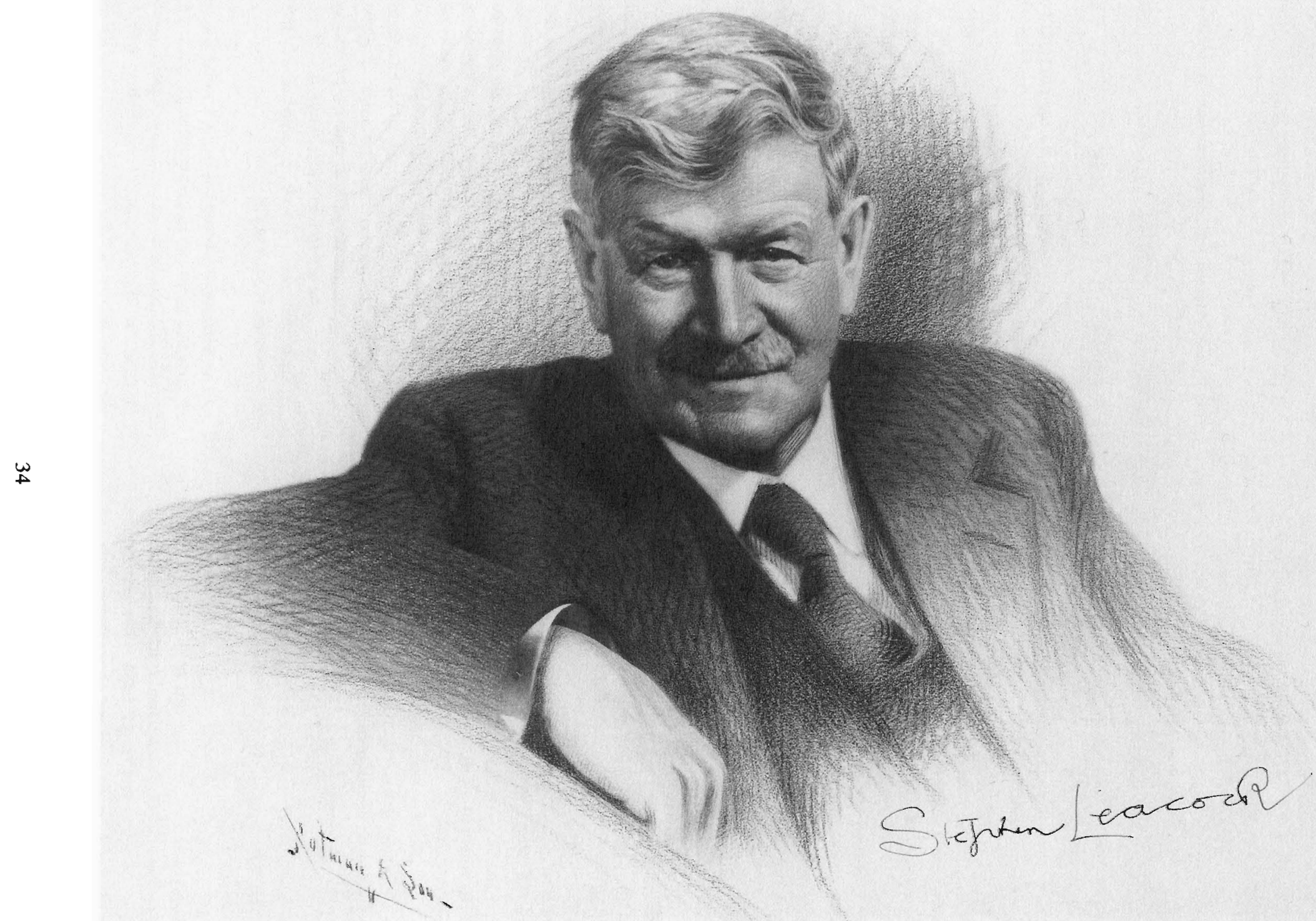


Leacock himself helped found the University Club of Montreal so that he would have quick access to a smoke and drink between lectures. Things had not changed much by the time I arrived in the late 1950s. My economics professor used to say that so far as he was concerned, the best drink of the day was the second, which was the one he had while he was shaving.

The ambition of undergraduates in the late fifties was not to achieve academic superiority, but to achieve what was called "effortless superiority" with emphasis on the effortless. This led to a practically comatose student body.

Graduates who went abroad to study used to write back to those of us still at the College and say that what they missed most about McGill was the apathy.

The McGill Daily ran a column entitled "McGill Life." The title was dropped when it was pointed out that the expression "McGill Life" was itself an oxymoron.

The same low energy levels are apparent today. Queen's graduates stage an annual marathon. Western graduates have their jog-a-thon. Even Concordia University graduates hold a walk-a-thon. The McGill Graduates' Society (at least in Toronto) can muster no more than a telethon, and even then complaints of over-exertion are common.

Let us now examine the second pillar of the McGill Mission Statement — "scholarship."

An appeal to love of scholarship is not likely to advance the interest of the McGill 21st Century Fund. Certainly, serious thinking was never tolerated in the Arts Faculty in my day.

Professors lecturing in Moyes Hall elicited so little reaction that Professor George Catlin used to say that talking to his political science students was like addressing the centre court at Madam Tussaud's waxworks.

Leacock himself saw only too clearly the marginal role scholarship played at the University in his day. On the death of Sir Arthur Curry, Leacock wrote:
General Sir Arthur Curry, Principal and Vice Chancellor of the University, knew nothing of scholarship in the narrower sense of the term. His dusty shabby professors were always a sort of mystery to him. He never could quite understand whether they were researching or loafing. When he first came to us, he imagined that the professors were always buried in the library, each lecture planned and prepared like Vimy Ridge.

Later on, he was a little disillusioned. "Some of the gentlemen," he said, only that was not the name he used for them; he had a simpler one "don't research at all." They were like hens who wouldn't lay. ${ }^{1}$

The third pillar of the Mission Statement is "service to society."

In my line of work, I often bump into graduates of the McGill Faculty of Law. I find that they are not especially keen on "service to society." Their clients say that it is as easy to open an oyster without a knife as to open the mouth of a McGill law graduate without a fee.

A former Dean of the Law School reportedly declined an appointment to serve society as a judge of the Supreme Court of Canada on the basis that he would rather talk drivel half the day than to listen to drivel all day as a judge on the nation's highest court.

The McGill News recently reported that zoology students were studying the differences between a McGill law graduate and a blowfish - their analysis showed that one is a wide-mouthed, bottom-feeding scavenger, and the other is a fish.

If one cannot find a high-minded dedication to "service to society" even among the lawyers, what can be expected from the more grasping professions such as medicine and engineering? The third pillar collapses under its own weight.

These three pillars of the McGill Mission Statement - teaching, scholarship and service to 
society - are set forth in a serious way at page 9 of the University Task Force on Priorities, May 1991, where it is said that they

derive from the fact that since its inception nearly two hundred years ago, McGill has been dedicated to the advancement of learning.

This, of course, is historical nonsense. It is refuted by the University's own official history, edited by Hugh MacLennan, published under the auspices of the McGill Graduates Society in 1960.

MacLennan documented the fact that the early years of the University were devoted not to the advancement of learning but to protracted litigation with the heirs of James McGill, who claimed that the old furtrader's dream of founding a university merely demonstrated a lack of testamentary capacity. While McGill's Royal Charter was granted in 1821, the project remained trapped in the courts for years like the great case of Jaryndyce $v$. Jaryndyce in Dicken's Bleak House into which lawyers were born and out of which they died. Eventually the Judicial Committee of the Privy Council put an end to the litigation with an award in favour of the University Trustees. By that time the estate was depleted, and Montreal lawyers rejoiced in a special McGill college grace which they said before meals:

Let strife continue at McGill College,

O Lord, lest these thy servants starve.

MacLennan's history tells us at page 53 that when Sir William Dawson became Principal in 1855, the present campus - the Burnside Estate of James McGill - was devoted not to the advancement of learning but to the pasturing of cattle. Dawson established a School of Engineering but it attracted no community support and had to be suspended amidst widespread public apathy. ${ }^{2}$ In 1871 , in assessing progress during the 50 years since the Royal Charter, Sir William Dawson chronicled the rising tide of apathy on and off the campus:

[The Chair of Practical Chemistry] failed to attract our artisans or manufacturers to receive its benefits, and the same fate has befallen my own efforts to bring the principles of Scientific Agriculture under the notice of our farmers ${ }^{3}$

This shows, I think, that in the latter part of the nineteenth century the whole scientific side of McGill was almost cancelled for lack of interest.

William Dawson's own devotion to "the advancement of learning" drifted into religious mania. The mid-1870s were consumed with his fight against musical church services, and in particular, the installation of a pipe organ at his beloved Erskine Presbyterian Church. As Sir William warned his fellow parishioners - music may be the food of love but it could become the aperitif of lust.

Lust, and the means of its containment, has been central to the minds of the University authorities for more than a century. It is interesting and significant, I think, that no mention is made of this bitherto paramount objective in the current McGill Mission Statement.

No one who lived through it will ever forget the great curfew controversy at Royal Victoria College in 1958. A McGill Daily editorial contended that the curfew was ineffective because whatever the students could do after 11:00 p.m. could be done with equal facility before 11:00 p.m. - to which the University replied that all of that was true but without a curfew the students could do "it" again.

Now we come to Sir William Peterson, who was appointed in 1895, after Sir William Osler refused even to consider returning to McGill from his refuge at the University of Pennsylvania. Dr. Peterson was from the Old Country and, according to MacLennan's history, was as little able as Sir William Dawson to get anyone interested in the advancement of learning. A graduate of the class of 1912 described his graduation ceremony, held at Royal Victoria College, as follows:

Dr. Peterson's deep drawling voice was well-known and easily imitated. When he addressed the graduating class these imitations, as well as cat calls and the almost incessant ringing of cowbells, drowned practically everything. ${ }^{4}$ 
Accordingly, nobody with any respect for McGill's history is going to contribute $\$ 200$ million or any part thereof to the 21st Century Fund on the strength of the fanciful claim in the Mission Statement that,

Since its inception nearly 200 years ago, McGill has been dedicated to the advancement of learning.

Leacock himself poked fun at fundraisers who were careless with their delusions.

In the Spring of 1925, his old graduate school, the University of Chicago, launched a major campaign for $\$ 17.5$ Million, an amount in those days that is perhaps comparable to $\$ 200$ Million today. Leacock responded as follows:

I have just learned that the University of Chicago is asking for $\$ 17.5$ million. I regret that I had not known of this sooner, but $I$ hasten at once to enclose my cheque for $\$ 17.5$ million with my best wishes for the continued success of my Alma Matter.

In entering this subscription on your list, I would ask you not to mention my name, but just mark it as from "a friend."

The only stipulation or caution I would like to make in regard to this donation is in reference to the cashing of the cheque. It ought to be cashed very carefully....I would like to say that when I was a student at Chicago, they used to cash my cheques at a little delicatessen store on Cottage Grove Avenue, and I am sure if this cheque were taken there, they would cash it without hesitation.

After being cashed, this cheque should be laid in a warm place, not exposed to the damp, and covered up at night. ${ }^{5}$

The fifth component of the McGill Mission Statement is to offer "to outstanding undergraduate and graduate students the best education available."
The type of student the University has in mind today was amplified in the Principal's message accompanying the 1991-92 McGill Annual Report at page 5 - a message that goes to great lengths to differentiate the students of the 1990s from the academic roadkill (including those of us here today) that preceded them. The Principal asked:

What kind of student attends McGill University in the 1990s?

The Principal answered his own question as follows:

From all parts of the University, deans and department chairs speak eloquently this year of exceptional academic performance and steadily rising standards.

Rising - evidently - from the low estate in which today's luncheon guests left them. The Principal continued:
Yes, our students are outstanding - but something more. They come to McGill ... because they welcome the prospect of a diverse and complex community, an international University that teaches 35 different languages within the context of a dialogue between two great linguistic cultures.

Students inhabiting the campus in the late 1950s and early 1960s presented a different picture. Most were still suffering severe after-effects from the onslaught of puberty. It was sometimes said that the only thriving culture on campus at that time was the yogurt sold in the Union cafeteria.

The prevailing educational philosophy was that students learned most from each other, and the task of the University was to provide a congenial setting for reflection, friends, youthful indiscretions and the sharing of laughter.

It was an unpretentious environment.

Theatre flourished. No one who saw it will ever forget such campus events as the McGill Dramatic 
Society production of Anthony \& Cleopatra. Picture the death scene - Mark Anthony stage left, fallen on his sword - visibly belching from a Ben's smoked meat. Noises off stage right - stage hands banging garbage pails with sticks. Roman legions at the gates of the palace. Trumpets and alarums. Cleopatra makes her speech about immortal longings, clasps the poisonous asp to her bosom, and with a scream falls dead. In the stunned silence that follows, the wife of the Principal F. Cyril James is heard to exclaim under her breath: "How different from the home life of our own dear Queen."

Of course, she spoke of our dear Queen's home life of 30 years ago.

While student preoccupations may have changed in the intervening years, I doubt it. Two of my sons who recently graduated from McGill told me that the ghetto was still a good place to live if you didn't mind being awakened every morning by the sound of five thousand electric hair blowers.

The sixth and final component of the McGill Mission Statement is to carry out:

scholarly activities judged to be excellent when measured against the highest international standards.

Everyone will concede that McGill has produced many scholars of world reputation. Sir William Osler, Dr. Wilder Penfield, Professor Ernest Rutherford and Dr. Frank Scott are recognized examples. But these are not the kind of scholars who capture the true genius of McGill.

It is no great achievement for someone endowed with a world class brain to put in a world class performance.

The real challenge is faced by the professors without world class brains.

Any university will bask in the reflected glory of a professor who gets things right.

The true test of a university is what it does when a professor makes a world class fool of himself.
Leacock himself put the University to this test when in the spring of 1930, as the world descended ever deeper into the great depression, he published a tendentious treatise entitled Economic Prosperity in the British Empire.

The book was an academic disaster both in Canada and abroad.

One foreign academic commented that, "Leacock is never funnier than when writing seriously about economics. ${ }^{16}$

The Times of London attacked Leacock's scholarship in the following terms:

[the book] bristles with questionable epigrams, skates lightly over practical issues and waives aside both economic theory and statistical method. Few economists will be impressed with the shortcuts the author takes "through the jungle of statistics," or with his pieces of "financial magic" in which something is made out of nothing.

According to the precepts of the McGill Mission Statement such a negative reaction would probably be fatal to an academic career at McGill today. But in those days the University community rallied around the faltering professor.

Leacock himself, with his usual panache, returned to the attack. He wrote:

In dealing with the mass of statistical material that goes with the making of such a volume as the present, it is unavoidable that errors and misprints will find their way in. For these I apologise. For instance, in Chapter III I stated that the number of hogs in the world is $200,000,000$. I now believe this is wrong. There seems to be more than that.

The Orillia Board of Trade, showing devotion to its prickly summer resident, bought 1,000 copies of the book and mailed a copy free to every British MP 
and to numerous newspaper editors throughout the United Kingdom.

Who best represents the spirit of McGill? Sir William Osler with his world class brain, showered with accolades from every quarter, or Stephen Leacock, bloody but unbowed, whose only allies in a losing cause were the remnants of his own Department of Political Economy and the despised Chamber of Commerce of the Town of Orillia?

McGill teaches its students the panache to sustain humiliating defeat without letting it show. This was a vital part of our eduction. By and large McGill graduates do not spend their life in the fast lanes. We pass our days in life's little collector lanes and the only fire in our belly is indigestion.

Our heroes are people like the members of the beloved McGill Redmen Marching Band.

Anybody can produce an outstanding marching band if they have people who can march and play musical instruments at the same time.

The genius of McGill was to produce a marching band whose members could do neither - at the same time or sequentially - an extreme example of panache in motion.

No doubt, Mr. Chairman, you are asking what conclusions I draw from this loosely reasoned analysis of the McGill Mission Statement.

Firstly, I say that McGill should put aside its newly developed world class neurosis about whether or not it is world class.

Secondly, a Mission Statement that cannot pass a reality check on any of its six major components should be returned to the drawing board.

Thirdly, the McGill 21st Century Campaign Fund should base itself on a Mission Statement more in tune with the Leacock way of looking at university life. If he had prepared such a document, he would probably have talked about some of the things that I have tried to describe today as the enduring values of our University: the pursuit of effortless superiority

panache

laughter

youth

friendship

The Leacock Mission Statement wouldn't have to be written out. Generations of undergraduates have imbibed it.

Mr. Chairman, it is these qualities and not pretensions to Harvard North that bring 600 people together each October at this luncheon to celebrate McGill University and recall with affection the life and contribution of Professor Stephen Leacock.

We must not become too tiresomely reverent about an institution that has stood for scepticism and irreverence for nearly 200 years.

We should not demand worshipful deference from a group of graduates who were taught at this university not to be worshipfully deferential about anything or anyone.

We should throw overboard the current McGill Mission Statement.

We should embrace the enduring values of Stephen Leacock, and sit back and watch $\$ 200$ Million flow in from across the world.

\section{Notes}

1. David M. Legate, Stephen Leacock; a Biography (Toronto: Doubleday Canada, 1970), 189.

2. Hugh MacLennan, McGill, The Story of a University (London: G. Allen \& Unwin, 1960), 61.

3. Ibid.

4. Ibid., 88 .

5. Legate, 145.

6. Ibid., 203. 